
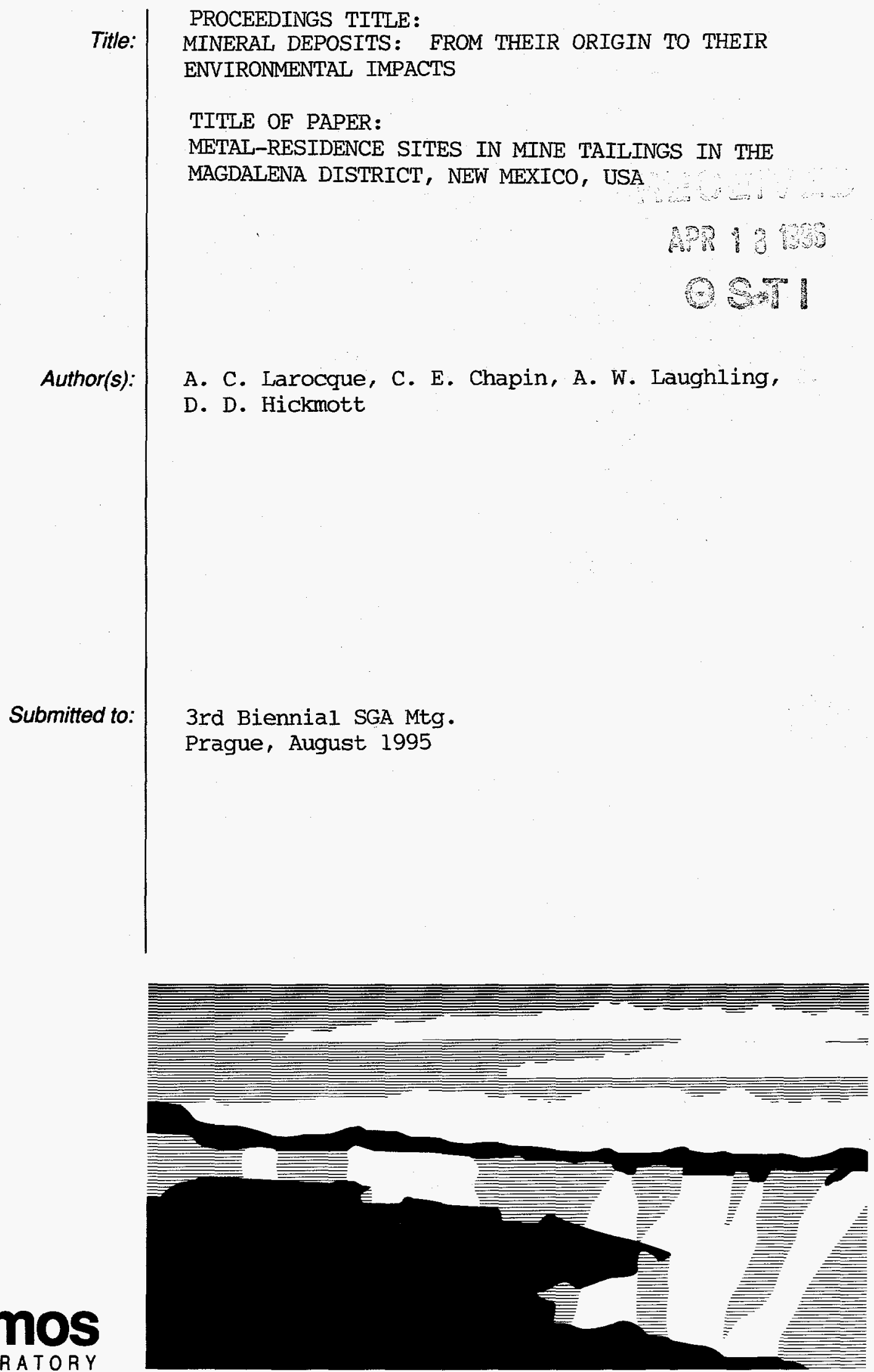

Los Alamos National Laboratory, an affirmative action/equal opportunity emplóyer, is operated by the University of California for the U.S. Department of Energy

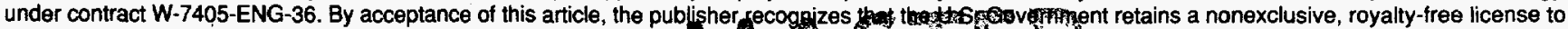

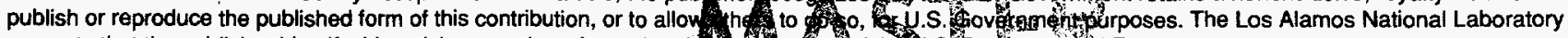

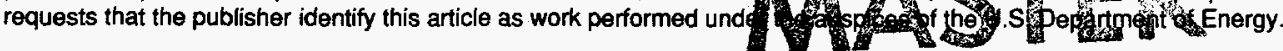




\section{Metal-residence sites in mine tailings in the Magdalena District, New Mexico, USA}

\section{Adrienne C. L. Larocque \\ Department of Geological Sciences, University of Manitoba, Winnipeg, Man., Canada}

Charles E.Chapin

New Mexico Bureau of Mines and Mineral Resources, N.Mex., USA

Socorro, N.Mex., USA

\author{
A.William Laughlin \\ ICF Kaiser Ltd, Los Alamos, N.Mex., USA
}

Donald Hickmott

EES-1, MS D462, Los Alamos National Laboratory

Abstract: Mineralization in the Kelly Mining Camp is hosted by the Mississipian Kelly Limestone and comprises $\mathrm{Zn}-\mathrm{Pb}$ skarn, replacement, and vein deposits related to Tertiary intrusive activity. The ore consists of primary (hypogene) sulfide mineralization which has been oxidized near surface to form secondary (supergene) mineralization. A zone of secondary sulfide-enrichment separates the sulfide and oxide ores. Mine tailings in the camp contain primary sulfide, oxide and gangue minerals, secondary (supergene) minerals formed during weathering of the primary ore, and tertiary minerals formed by alteration of hypogene and supergene assemblages after deposition in the tailings impoundment.

\section{INTRODUCTION}

Currently in North America, mines operate under stringent environmental controls. Environmental concerns have become an important factor in determining the viability of a mine, as costs related to environmental standards may increase the cost of production (and thus, the cut-off grade) of an orebody. Aqueous transport of metals, whether during the formation or degradation of ore deposits, is governed by fundamental processes. Understanding these processes is necessary in order to predict and possibly modify how metals move in our environment. The purpose of this paper is to present preliminary results of a study of the mineralogical residence sites of metals released by weathering of mine tailings in the Kelly Mining Camp of the Magdalena District in New Mexico, U.S.A.

\section{GEOLOGICAL SETTING}

The Magdalena Mining District is located in southcentral New Mexico in the southwest U.S.A. (Fig. 1) Precambrian sedimentary and igneous rocks form the core of the Magdalena Mountains. These are overlain unconformably by west-dipping Upper Paleozoic sedimentary rocks. Tertiary extrusive and intrusive rocks overlie and intrude the Paleozoic rocks, and are in turn overlain by Quaternary alluvial deposits.

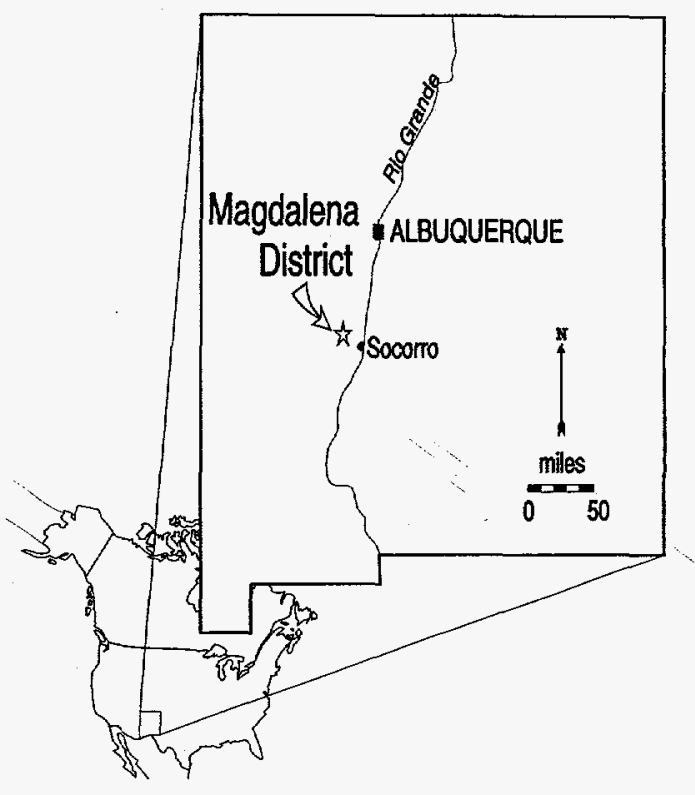

Fig. 1: Location of the Magdalena Mining District in south-central New Mexico, U.S.A.

Mineralization in the Magdalena District is hosted by Upper Paleozoic sedimentary rocks (Loughlin \& Koschmann, 1942). The sedimentary sequence comprises the Kelly Limestone (Mississippian age), the 
Sandia Formation and Madera Limestone (Pennsylvanian age), and the Abo Sandstone (Permian age). The Kelly Limestone was the most productive of the formations, and hosts the deposits of the Kelly Mining Camp. Throughout the camp, the Kelly Limestone consists of upper and lower calcic limestone separated by a bed of argillaceous limestone. The latter is called the "silver pipe" because of its close association with ore shoots (Loughlin \& Koschmann, 1942).

\section{PETROGRAPHY AND CHEMISTRY}

Mineralization in the Kelly Camp comprises $\mathrm{Zn}-\mathrm{Pb}$ skarn, replacement, and vein deposits related to Tertiary intrusive activity. The ore consists of primary (hypogene) sulfide mineralization which has been oxidized to form secondary (supergene) mineralization near surface. A zone of secondary sulfide-enrichment separates the primary sulfide and secondary oxidized ores. The hypogene ore assemblage in the Magdalena District is simple, consisting of sulfides of iron, zinc, lead, and copper, and oxides of iron. In contrast, the supergene ore assemblage is complex. It includes native copper and copper sulfides, as well as oxides, sulfates, carbonates, and silicates (many of them hydrous) of zinc, lead, copper, and iron (Table 1).

A combination of optical microscopy, X-ray diffraction (XRD), scanning electron microscopy (SEM) and electron microprobe analysis were used to identify the nature and composition of samples of mine tailings from the Kelly Camp. The samples contain primary sulfide, oxide, and gangue minerals, secondary (supergene) minerals formed in situ, and tertiary minerals formed by alteration of hypogene and supergene assemblages after deposition in the tailings pile. As alteration of primary ore minerals after deposition in the tailings pile may give rise to the same mineral species that are present in the secondary assemblage, genetic differentiation is based mainly on textural characteristics. Features such as continuous reaction rims and coating on grains are interpreted to have formed in the tailings pile; the constituent minerals are part of the tertiary assemblage (Figs. 2-5).

Primary ore minerals present in the tailings include pyrite, sphalerite, galena, chalcopyrite, and magnetite, all of which exhibit varying degrees of dissolution and alteration. Alteration products commonly consist of fine-grained mixtures, making quantitative analysis difficult. However, it is clear that metals released by weathering of primary minerals have been incorporated into tertiary phases.
Table 1. Ore Minerals in the Magdalena District*

Hypogene

Oxidized

$\mathrm{Fe}$ : limonite/goethite, hematite, jarosite, melanterite

$\mathrm{Zn}$ : smithsonite, hydrozincite, aurichalcite, hemimorphite, chalcophanite, goslarite, willemite

$\mathrm{Pb}$ : cerussite, anglesite, plumbojarosite, wulfenite, vanadanite

$\mathrm{Cu}$ : malachite, azurite, aurichalcite, chrysocolla, cuprite, tenorite, spangolite, cyanotrichite, antlerite, chalcanthite, native copper

Sulfide Enrichment

$\mathrm{Cu}$ : chalcocite, covellite

\section{Supergene}

Fe: pyrite, pyrrhotite, hematite, magnetite

$\mathrm{Zn}$ : sphalerite

$\mathrm{Pb}$ : galena

$\mathrm{Cu}$ : chalcopyrite, bornite

* from Loughlin \& Koschmann (1942)

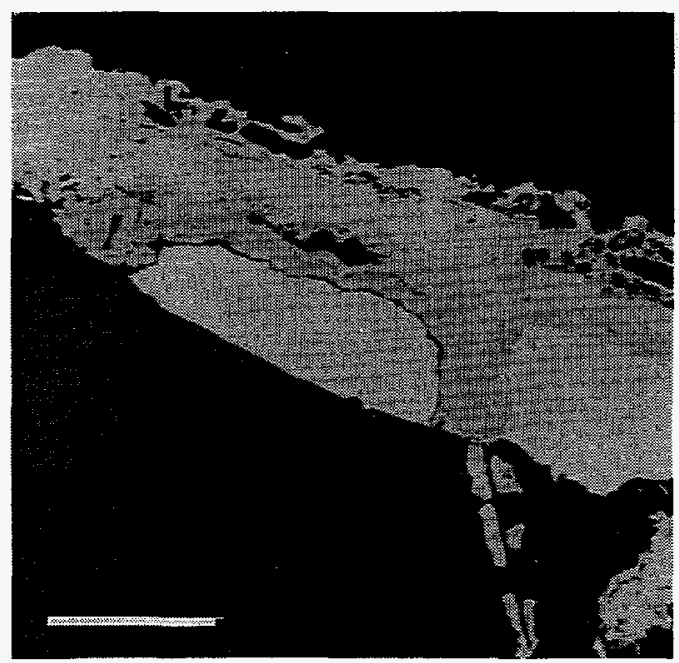

Fig. 2: Backscattered-electron image of intergrown galena (white) and sphalerite (dark grey). Alterion of galena consists of lead sulfate on outside surface and lead oxide(?) adjacent to galena. Scale bar: $50 \mu \mathrm{m}$. 
Primary pyrite commonly is corroded and altered to iron oxide or iron oxyhyroxide. In some samples, energy-dispersive X-ray (EDX) spectra of suspected iron oxides/oxyhydroxides exhibit zinc or copper peaks. This is consistent with solid-substitution of copper, zinc, and other trace metals in synthetic goethite (Gerth, 1990). Iron sulfate does not occur in alteration zones on iron sulfides, but likely is a component of fine-grained mixtures in coatings on grains.

Some galena grains are altered to lead sulfate and possibly lead oxide on exposed surfaces and along fractures (Fig. 2). Others are rimmed by fine-grained material which may contain a mixture of plumbojarosite and goethite. According to Jambor (1994), goethite and jarosite are two of the principal secondary products of the oxidation of iron sulfides.

Sphalerite grains commonly are corroded and coated with fine-grained material (Fig. 3). The compositions of the coatings vary from grain to grain, possibly because of variations in local chemical environments in the tailings, as well as variations in the iron content of the sphalerite. EDX spectra suggest that some of the coatings consist of jarosite. The fact that jarosite is capable of incorporating numerous elements in solid-solution (Jambor, 1994) may account for presence of zinc peaks in the spectra. Other sphalerite grains are rimmed by fine-grained zinc silicate (Fig. 3). A feathery tertiary phase containing iron, zinc, copper, and sulfur has been observed along the surface of one corroded sphalerite grain (Fig. 4). Although this phase has not been unequivocally identified, it may be related to filiform tertiary sulfates described by Jambor (1994, Fig. 3.9).

Calcite grains typically exhibit inward-growing reactions rims of zinc sulfate and bladed overgrowths of gypsum, formed during carbonate-buffered reactions with metalliferous acidic solutions (Fig. 5). Although zinc sulfate is highly soluble in tailings environments (Jambor, 1994), it is possible that the gypsum overgrowth prevented dissolution of zinc sulfate after it formed. Carbonates of lead, zinc, and copper have not yet been identified, likely because of the limitations of the analytical techniques employed thus far rather than the actual absence of these minerals. Future work will be directed at identifying these phases, as they are common products of the oxidation of $\mathrm{Pb}-\mathrm{Zn}-\mathrm{Cu}$ ores (Alpers et al., 1994)

In addition to precipitation as metal oxides, sulfates, and silicates (and possibly carbonates?), metals may be incorporated into secondary/tertiary minerals through ion exchange. Although textural relationships are ambiguous, obscurring the timing of

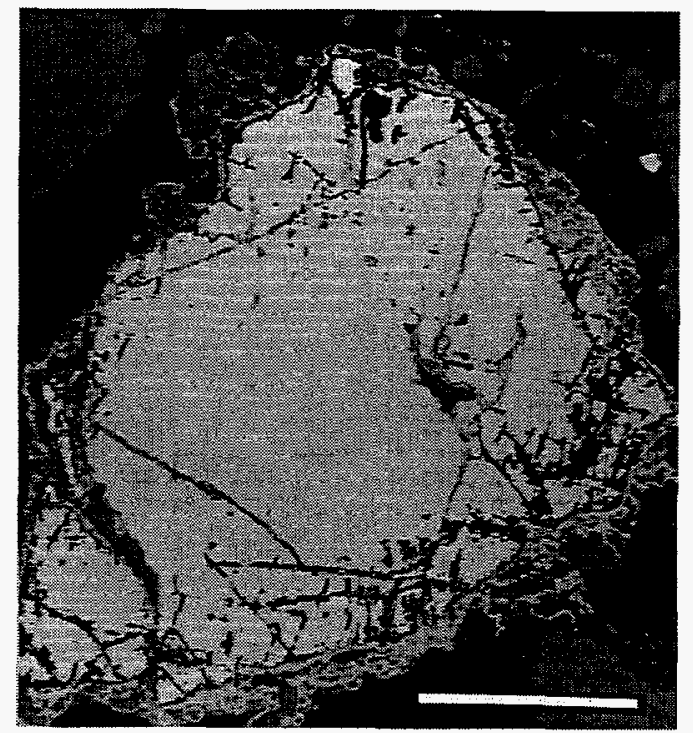

Fig. 3: Backscattered-electron image of corroded grain of sphalerite coated by rim of zinc silicate (light grey) with grains of calcite(dark grey). Scale bar: $500 \mu \mathrm{m}$.

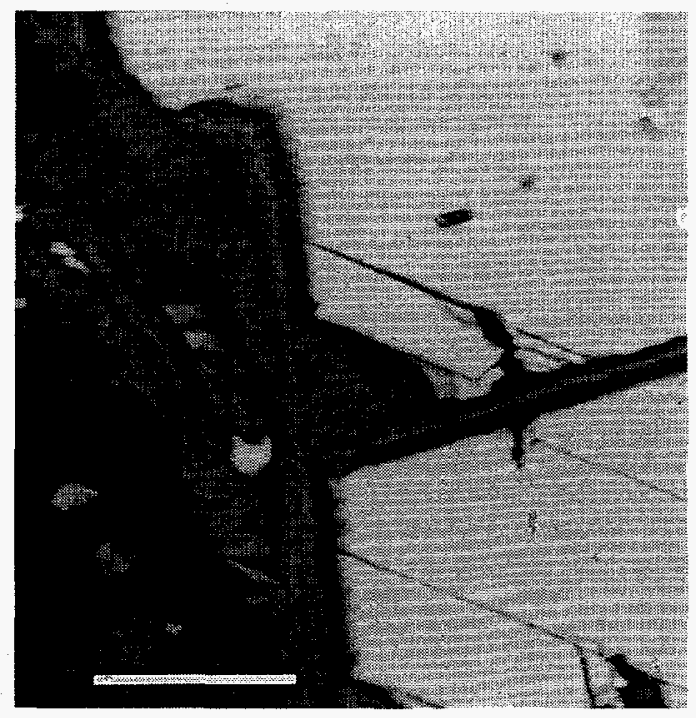

Fig. 4: Backscattered-electron image of sphalerite grain with feathery tertiary phase along surface and in fracture. Scale bar: $25 \mu \mathrm{m}$.

formation, EDX spectra of vermiculite alteration products of biotite indicate the presence of zinc. This relationship has been documented in soils developed on glacial sediments in Canada, and has been attributed to 


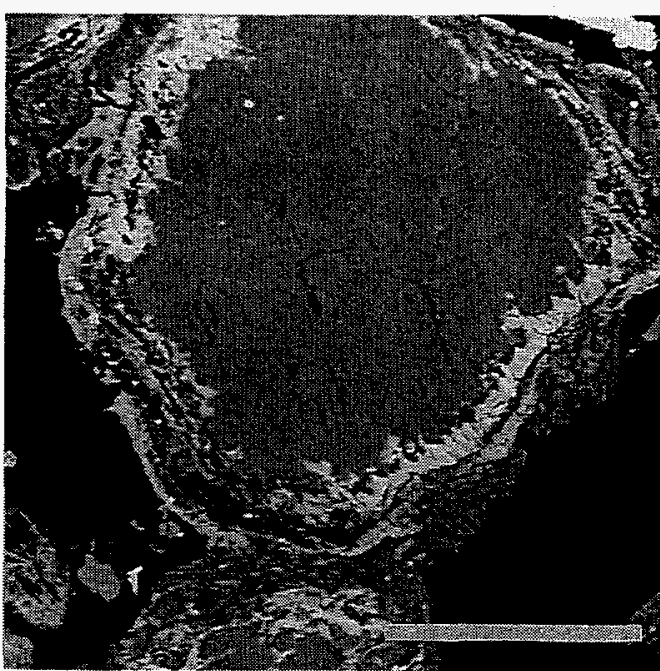

Fig. 5: Backscattered-electron image of calcite grain with inward-growing reaction rim of zinc sulfate (white) and bladed overgrowths of gypsum (dark grey). Scale bar: $200 \mu \mathrm{m}$.

progressive incorporation of zinc through ion exchange during weathering of biotite (Larocque et al., 1993). In addition, similar incorporation of copper into vermiculite has been observed associated with weathered copper mineralization in Brazil (Ildefonse et al., 1986) and in products of experimental weathering of biotite (Ilton et al., 1992).

\section{CONCLUSIONS}

In tailings in the Kelly Mining Camp, tertiary sulfate, silicate, and oxide minerals provide important sinks for metals released by chemical weathering of primary and secondary ore minerals. In addition to precipitation as metal compounds, metals have been incorporated into secondary/tertiary minerals through ion exchange.

\section{REFERENCES}

Alpers, C.N., D.W. Blowes, D.K. Nordstrom \& J.L. Jambor 1994. Secondary minerals and acid mine-water chemistry. In J.L. Jambor \& D.W. Blowes (eds.), Min. Assoc. Canada Short Course 22:247-270.

Gerth, J. 1990. Unit-cell dimensions of pure and trace metal-associated goethites. Geochim. Cosmoshim. Acta 54:363-371.
Ildefonse, P., A. Manceau, D. Prost \& M.C.T. Groke 1986. Hydroxy-Cu-vermiculite formed by the weathering of Fe-biotites at Salobo, Carajas, Brazil. Clays Clay Min. 34:223-345.

Ilton, E.S., D. Earley III, D. Marozas \& D.R. Veblen 1992. Reaction of some trioctahedral micas with copper sulfate solutions at $25^{\circ} \mathrm{C}$ and 1 atmosphere: an electron microprobe and transmission electron microscopy investigation. Econ. Geol. 87:1813-1829.

Jambor, J.L. 1994. Mineralogy of sulfide-rich tailings and their oxidation products. In J.L. Jambor \& D.W. Blowes (eds.), Min. Assoc. Canada Short Course 22:59-102.

Larocque, A.C.L., H.W. Nesbitt, R.N.W. DiLabio \& G.D. Guthrie 1993. Fixation of $\mathrm{Zn}$ by vermiculite in weathered glacial sediments. Geol. Soc. America Abstr. Prog.25:A234.

Loughlin, G.F., \& A.H. Koschmann 1942. Geology and Ore Deposits of the Magdalena Mining District, New Mexico. U.S. Dept. Interior, Prof. Paper 200, 168 p. 
Blenkinsop, Tom G. \& Paul L.Tromp (eds.)

9054106107

Sub-Saharan economic geology

(Geological Society of Zimbabwe Special Publication nt.3)

May 1995, $25 \mathrm{~cm}$, c. 300 pp., Hfl. $165 / \$ 95.00 /$ f61

Emphasis is on new mines, new exploration activity and methods, and new ideas in the Sub-Saharan sector. Topics: Base metals, greenstones and ultramafic rocks; Softrock, hydrogeology, geophysics and diamonds; Gold at any price; Structural geology; Shamva

Greenstone belt; Coalbed methane \& Karoo.

\section{Kesse, G.O.}

The mineral and rock resources of Ghana

9061915899

$1985,25 \mathrm{~cm}, 624 \mathrm{pp}$., Hfl. $270 / \$ 135.00 / £ 100$

Importance of minerals; Ghana: Geography, physiography, geology

\& geohydrology; Mineral resources of Ghana: background; Metallic \& non-metallic minerals; Bulk construction materials; Radioactive minerals; etc. Author. Director Geol. Survey Dept. of Ghana.

Bhaskar Rao, B.

Metamorphic petrology

$1986,22 \mathrm{~cm}, 190$ pp., Hfl. $120 / \$ 70.00 / £ 45 \quad$ (No rights India) Experimental petrology; Techniques used to decipher the genesis of metamorphic rocks; Introductory thermodynamics: Understanding the history of metamorphic rocks.

Abramovich, I.I. \& I.G. Klushin

Geodynamics and metallogeny of folded belts

9061919320

$1990,24 \mathrm{~cm}, 255 \mathrm{pp}$., Hff. $150 / \$ 85.00 / £ 55$

(Russian translations series, 78) metallogeny on global perspective and specific sinuations for the formation of copper-molybdenum, tin-wolfram, mercury, lead-zinc and fluorite provinces. Geodynamic models; Metallogenic investigations of geodynamic models; Paramount indicators of the geodynamic regime; Copper-Molybdenum porphyry ore provinces; etc.

Pagel, Maurice (ed.) 9054100206 Source, transport and deposition of metals - Proceedings of the SGAAnniversary Meeting, Nancy, 30 August-3 September 1991 $1991,25 \mathrm{~cm}, 850$ pp., Hfl. $245 / \$ 140.00 / £ 91$
Brazil Gold '91 - The economics, geology, geochemistryand gen-

esis of gold deposits - Proceedings of the symposium Brazil Gold

'91, Belo Horizonte, Brazil, 13-17 May 1991

$1991,25 \mathrm{~cm}, 844$ pp., Hfl. $225 / \$ 130.00 / £ 85$

Foster, R.P. (ed)

$906191504 \mathrm{X}$

Gold 82: The geology, geochemistry and genesis of gold deposits Proceedings of the symposium Gold '82, University of Zimbabwe, 24-28 May 1982

(Geological Society of Zimbabwe Special Publication, 1)

$1984,25 \mathrm{~cm}, 764$ pp., Hfl.270/\$165.00/£100

Akramkhodzhaev,A.M., V.A.Babadagly \& A.D.Dzhumagulov Geology and exploration of oil- and gas-bearing ancient deltas $1989,24 \mathrm{~cm}, 213$ pp., Hfl. $165 / \$ 95.00 / £ 61$

(Russian translations series, 69) $906191907 \mathrm{X}$ Geological structure of deltas; Thermodynamics \& geochemistry of sedimentary rocks: Generation \& accumulation of hydrocarbons: Oil- \& gas-bearing ancient deltas in the USSR \& other countries; Methods of studying the oil \& gas potential of ancient deltas; etc.

Oti, M.N.\& G.Postma (eds.)

$905410614 \mathrm{X}$

Geology of Deltas

June $1995,28 \mathrm{~cm}, \mathrm{c} .340 \mathrm{pp}$. , Hfl.195/\$115.00/£73

Deltas occur on every continent across the earth and their deposits span the geological record from the Precambrian to the Holocene. The book presents an in-depth exposition of some of the world's deltas, presented at the LAS sponsored international symposium, Port Harcourt, Nigeria, 1992. General considerations; Delta facies and architecture; Aspects of sedimentary petrology and diagenesis in deltas; Niger Delta: Exploration and production perspectives. 21 papers.

Bickle, M.J., A.Martin, E.G.Nisbet \& J.L. Orpen (eds.) The geology of the Belingwe Greenstone Belt, Zimbabwe: $A$ study of Archaean continental crust

$1993,25 \mathrm{~cm}, 248 \mathrm{pp}$., Hfl. $165 / \$ 95.00 / £ 61$ 9054101202

Stratigraphy of the Belingwe Greenstone Belt: Complexity of the tectonic setting; Structure and metamorphism of the Belingwe Greenstone Belt and adjacent granite-gneiss terrain: The tectonic evolution of an Archaean craton; The Mitchinge Group in the West: Andesite, basalts, komatites and sediments of the Ilokonui, Bend and Koodoovale Formations; Sedimentology of the Brooklands Formation, Zimbabwe: Development of an Archaean greenstone belt in a rapidly rifted graben; etc. 9 papers.

\section{DISCLAIMER}

This report was prepared as an account of work sponsored by an agency of the United States Government. Neither the United States Government nor any agency thereof, nor any of their employees, makes any warranty, express or implied, or assumes any legal liability or responsibility for the accuracy, completeness, or usefulness of any information, apparatus, product, or process disclosed, or represents that its use would not infringe privately owned rights. Reference herein to any specific commercial product, process, or service by trade name, trademark, manufacturer, or otherwise does not necessarily constitute or imply its endorsement, recommendation, or favoring by the United States Government or any agency thereof. The views and opinions of authors expressed herein do not necessarily state or reflect those of the United States Government or any agency thereof.

All books available from your bookseller or directly from the publisher: AA Balkema Publishers, P.O. Box 1675, Rotterdam, Netherlands For USA \& Canada: AA Balkema Publishers, Old Post Rd, Brookfield, VT, USA 